811.161.1'373(091)

811.163.41'373(091)

https://doi.org/10.18485/sj.2017.22.1.26

\section{Е. Р. БАЙОВИЧ}

Университет в г. Косовска-Митровица

Философский факультет

Кафедра русского языка
Оригинални научни рад

Примљен: 01. 09. 2016.

Прихваћен: 15. 12. 2016.

\title{
К ВОПРОСУ О ФОРМИРОВАНИИ ТОРГОВО-ЭКОНОМИЧЕСКОЙ ЛЕКСИКИ \\ В РУССКОМ И СЕРБСКОМ ЯЗЫКАХ (НАЗВАНИЯ ТОРГОВЦЕВ ТКАНЯМИ)
}

\begin{abstract}
В настоящей работе рассматривается история распространения и семантического развития названий торговцев тканями в русском и сербском языках в сравнительно-историческом и сопоставительном аспектах. Исследование строится на материале Картотеки древнерусского языка (КДРС), на основе которой создается «Словарь русского языка XI-XVII вв.». В первую очередь прослеживается история названий торговцев тканями, предметов одежды и подержанной одежды в русском языке, далее последовательно рассматривается история данных слов в сербском языке.
\end{abstract}

Ключевые слова: историческая лексикология, торгово-экономическая лексика, названия торговцев тканями.

0. Анализ широкого круга торговых понятий в русском и сербском языках позволяет наметить основные характеристики лексического наполнения данного семантического пространства, сделать определенные шаги в осуществлении описания лексики двух языков и совершенствовании лексикографической практики.

*j.bajovic@yahoo.com 
Торгово-экономическая лексика Древней Руси, исторические предпосылки становления сопутствующих явлений и развитие тематических групп, рассматривались нами в предыдущих работах (см. Мароевич 2002а $2002^{\sigma}, 2004$ и Байович 2015, 2016).

1. Торговля тканями в Древней Руси с XV в. стремительно развивалась и уже в XVI в. Москва считалась одним из центров полотняной торговли, куда стекались товары со всего мира. Хотя англичане, персияне, голландцы и другие постоянные «гости» активно привозили в Русь свои ткани, не менее заметную роль в развитии ткацкого дела сыграли русские производители и торговцы.

На протяжении веков традиционным русским товаром считался лен, а изготовлением его для пряжи занимался мастер под названием ольненикъ (ольленикъ, олленикъ). Продажа льняного волокна и изделий из льна происходила в льняном (ольняном) ряду, а торговал товаром льняникъ: 57. 1578 г

Связок лну за полтину дал вкладом Иванъ лняник. Кн. прих.-расх. Ант. м. № 1,

Особым видом грубой льняной ткани под названием холсть торговал холщевникъ. Аксамитникъ (оксамитникъ) изготовлял и продавал аксамит - драгоценную ткань с золотыми и серебряными нитями в основе. На древнерусском рынке присутствовали и другие ремесленники, продающие ткани разного вида: бархатникъ, войлочникъ, камочникъ (торговавший камкой - шелковой узорчатой тканью), шелковникъ, шерстеникъ. Торговец изделиями из шерсти клобучникъ зафиксирован в документе, относящемся к XII-XIV вв.

Продажей пестрых и разноцветных тканей занимался пестродюлатель (пестрядинникъ, пестрединникъ, пестрядильникъ). Ткани и покрывала изготовлял пеленочникъ, а обшивкой не только тканей, но и готовой одежды занимался ошивальникъ.

Сохранился целый ряд слов, обозначающих человека, занимающегося ткацким делом: ткалещъ, ткатель, ткачь, точай (тъчай), хамовникъ и бралья (ткачиха, изготовляющая браную, т.е. узорную ткань). В КДРС содержатся примеры, указывающие, что люди, занимающиеся прядением на Руси (прядея, прядильщикъ и прялья) в процессе торговли обычно не участвовали, а получали годовое денежное жалованье. Для полной картины устройства средневекового производства тканей мы приведем и ремесленников, занимающихся обработкой полотна. Это колотильникъ или колотильщикъ (мастер, колочением обрабатывающий ткани), мочильщикъ (тот, кто занимается мочением сукон), топтальникъ (человек, валяющий сукно) и крашенинникъ:

А в ряду я спрашивалъ крашенинниковъ, по чему от крашенинъ емлютъ отъ красокъ; и они сказали: от ценинной и отъ яринной по четыре деньги и по три деньги. Пис. к Безобразову, 7. 1681 г. 
2. На сербской территории торговля тканями также была хорошо развита, но имелись свои приоритеты в производстве, связанные с географическими и экономическими особенностями. Продажа изделий из льна не была в числе ведущих, но все же отмечена в документах. Лексема lanar 'человек, который занимается льном: изготовляет, расчесывает, продает' употребляется с XVII в., а форма prtenar с тем же значением упоминается только в двух словарях начала XVIII в.

Торговлей тканями в широком смысле слова занимались platnar, postavar (в Речн. ист. хорв. серб. также зафиксирована форма postavljar, но с отметкой, что авторы в нем не уверены) и vilahnar. Все три лексемы появились в языке на рубеже XVII-XVIII вв.

Изготовлением и продажей изделий из хлопка занимался ратис̌аr, из тур. pamuk или pamluk, а это, в свою очередь, из перс., откуда и греч. $\beta \alpha ́ \alpha \beta \alpha \xi$, $\beta \alpha \mu \beta a ́ q ı v$, а оттуда и лат. bambax, bambagium). Это слово, употребляющееся и в современном сербском языке, наряду с названиями лавок, в которых продавался данный товар - pamuс̌аra и ратис̌arija, впервые записал Вук Ст. Караджич в своем словаре середины XIX в.

Человек, занимающийся изготовлением и продажей сукна и изделий из этого материала под названием svitar в памятниках письменности отмечен с $\mathrm{XV}$ в.:

Za Ivana svitara i za Antona trumbbetaša, što nam Toliša govori, razumjesmo i njemu odgovorismo (По поводу Ивана, торговца сукном, и Антона трубача, мы поняли и ему ответили). (Dubrovčani vojvodi Sandalju, 1406) Spom. srp. 1, 82.

Формы suknar и suknotkalac с таким же значением, стали использоваться в языке значительно позже: с середины XVII и первой половины XVIII в. соответственно.

Место, в котором продавалось полотно под названием bezistan, bezisten восходит к араб. bezzistan в этом же значении.

Слово svilar, обозначающее человека, изготавливающего шелк или продающего его, впервые встречается у писателя второй половины XVI в. Марина Држича:

Na veliki ti prepozit izide ovi svilar (На большую вещь вышел этот торговец шелком). M. Držić 355 .

Форма svilotržac появляется приблизительно на век позже, но в языке не удерживается. Магазин, в котором осуществлялась торговля шелковыми товарами svilarnica зафиксирован в документах только с XIX в.

В силу своего географического положения и благоприятных климатических условий, в сербских землях было хорошо развито скотоводство и име- 
лись большие запасы шерсти. Торговля изделиями из шерсти стала основным источником доходов жителей некоторых, преимущественно горных, районов. Лексема vunotržac 'торговец шерстью' отмечена только в одном источнике XVII в., позже она утрачена. Форма vunar в значении 'тот, кто обрабатывает шерсть' появилась в XVII в., а интересующее нас значение 'торговец шерстью' это слово приобрело в XIX в., когда возникает и название продавца лучших сортов шерсти - striževinar.

Название мастеров, занимающихся ткацким делом в сербском языке также как и в русском восходит к старосл. тъкачь. В Сербии эта форма дала следующие варианты: tkač (употребляется с XIV в.), затем tkalac (с первой половины XVI в.), и, наконец, takač и tikač с конца XVII в. Следующий материал из Хрисовули царя Душана относится к середине XIV в.:

\footnotetext{
I u Pusticahь dva vinograda i zamenismo ihь Ivanku tъkaču (И в селе Пустицы есть два виноградника, которые мы обменяли для Иванка ткача). Hris. cara Dušana, Glasnik $15,271$.
}

Подкладки для одежды шил и продавал мастер под названием potplatar.

3. В документах, собранных в КДРС и относящихся ко второй половине XVI и XVII вв., содержатся названия целого ряда мастеров, занимающихся изготовлением и продажей предметов одежды. Самую большую группу составляют ремесленники, которые шили верхнюю одежду и профессия которых получила название по готовому товару.

Просторные длинные халаты под названием балахоны изготовлял балахонещъ:

В[о дворъ $]$ Михалко Чюрин сапожник; в $[$ о дворъ $]$ Игнатко горшешник... в Калинка балахонец середней. Кн. п. Казани, 14. 1568 г.

Одним из редких мастеров, зафиксированных в XV в., был изготовитель кафтанов без воротника - однорядочникъ:

А у Мити у однорядочника взяли косякъ тафты червчатые ездинские да тясму шолкову, да рубль денегъ. Польск. д. І, 27. 1489 г.

Шитьем выходной одежды также занимались: сарафанникъ, армячникъ или ормячникъ (армяк - верхняя мужская одежда из сукна, шерсти), душегрпйникъ или душегриникъ (душегрейка - род короткой одежды), епанечникъ, опонечникъ, япанечникъ (епанча - род накидки, плаща, широкое длинное верхнее платье без рукавов), кафтанникъ, кавтанникъ, кофтанникъ; манатейникъ (мастер, который шьет мантии), рубашечникъ, свитникъ или свиточникъ (свиты - род верхней или нижней одежды, преимущественно священнослужителей и монахов), сермяжникъ (сермяга - грубое некрашеное сукно, а также кафтан из такого сукна), тегиляйный человпкъ (тегиляй 
- кафтан со стоячим воротником и короткими рукавами), тюлогрпийникъ или тюлогртнникъ (телогрея - род простонародной одежды наподобие душегрейки, длинной во весь рост, застегивавшейся пуговками от верха до подола), терличникъ (терлик - узкий кафтан с талией и короткими рукавами), ферезникъ (ферезь - мужское долгое платье с длинными рукавами, без воротника и перехвата), чекменникъ (чекмень - крестьянский кафтан, короткий полукафтан с перехватом).

В значении изготовителя штанов мы в КДРС обнаружили лексемы порточникъ и ногавичникъ. Носками, получулками, вязеной долгой обувью и гамашами в Древней Руси торговал чулочникъ (чулошникъ).

Разного рода варежки и рукавицы продавали варежникъ, голяничникъ, дъяничникъ (деяницы - вязаные рабочие рукавицы) и рукавичникъ:

Гришко Кузминъ, рукавишникъ, въ роспросе сказывался... живетъ де онъ, Гришка, на монастырской... землъ въ сосъдствъ у Кирилка плотника; а кормитъ де ся онъ, Гришка, скупая руковицы на бозаре, продаетъ. А. закл. 203. 1643 г.

Неотъемлемой частью русского костюма были головные уборы, изготовлением и продажей которых на Руси занимались: каптурникъ или капторникъ (каптур - теплая шапка с круглым верхом, меховая или стеганая, с пелериной, спускавшейся с верху и прикрывавшей шею и плечи), киверникъ (кивер - высокий головной убор из жесткой кожи с козырьком), кичечникъ (кичка - праздничный головной убор замужней женщины), колпачникъ, шапочникъ и шиляпникъ.

Мастер, изготовляющий и продающий узорчатую отделку для одежды, изделий из тканей, назывался кружевникъ или кружевочникъ:

Кружевныхъ дъль мастеру Федору Воробью для твоихъ государевыхъ кружевныхъ дъль и для учениковъ данъ ему быль дворъ въ Китаъ городъ... И того Федора кружевника въ животъ не стало. Заб. Ик., 80. 1668 г.

Нашивками торговал нашивочникъ, а золотом расшивал одежду и головные уборы мастер, носивший название золотошвей, золотошвея, золотошвещъ:

[Дано] нашивочнику Данилъ Алексъеву за нашивки маленькия золотныя и серебреныя... 6 р. 18 ал. 4 д. Арх. бум. Петра I, 270. 1684 г.

Золотошвеъ старцу Мисаилу на 2 золотника шелку 2 алт., да на золото 5 алт., сдълалъ къ государевымъ патриарховымъ четкамъ кисть. Заб. Мат. I, 951. 1628 г.

Расшивал одежду и ткани, а также обтягивал пуговицы, ремесленник под названием канительникъ (конютельникъ, кинительникъ) и канительщикъ (кинительщикъ). 
Карманы шил карманникъ, а кошельки (мошны), сумки, мешочки для мелких ценных предметов-мошенникъ. Чехлы для огнестрельного оружия, которые называли ольстры, обычно из бархата делал ольстрплльникъ. Изготовлением поясов занимались поясникъ и татаурникъ (татаур - широкий, иногда шитый золотом боярский пояс), а обшивкой свободно свисающими нитями занимался бахромщикъ (бахрамщикъ).

Аксессуарами к одежде торговали пугвичникъ (пуговичникъ), булавочникъ и завязочникъ, на рынке даже существовал специальный ряд - завязочный, где можно было купить необходимые для шитья мелочи:

Завязочнику Сенкъ Иванову ото 100 отъ 9 портищъ шолковыхъ завязокъ, отъ дъла... 28 алтынъ 2 денги. Кн. прих.-расх. Каз. пр., 131. 1614 г.

Для полноты картины организации средневекового текстильного производства необходимо привести и названия мастеров, которые непосредственно шили предметы одежды: портной, портной мастеръ (иваль, щвецъ), ризношвець (ризошвець).

В числе мест торговли предметами одежды в СлРЯ XI-XVII вв. отмечены кафтанный, крашенинный и сермяжный ряды.

4. Сербские памятники письменности, к сожалению, фиксируют производителя и торговца готовым платьем под названием stupar только в одном примере XVI в. Другой материал, содержащийся в Речн. ист. хорв. серб., более поздний. Ремеслом изготовлять одежду владел отмеченный в XVII в. odjećnik, в более поздних материалах odjećar. Приблизительно к этому же периоду можно отнести изготовителя рубашек, называющегося stomanjar, а формы с таким же значением rubačar и košuljar появились на век позже. К XVIII в. также относятся названия kaftandžija (из перс. тур. qaftân) и торговец бельем rubljar. В XIX в. отмечены торговцы одеждой haljinar и ruhar, плащами - kabaničar и пальто - surdomar.

Что касается торговцев головными уборами в сербских землях, то особо следует выделить слово klobučar, т.к. еще в документе 1293-1302 гг. в перечислении мастеров упомянут Strezo klobučarь. Mon. serb. 63. Форма klobučnik появилась значительно позже - в начале XIX в. К этой же группе торговцев относятся kalpakčija или kalpagdžija в значении 'изготовляющий колпаки' из тур. qalpaqčy, kukuljar 'тот, кто делает и продает кукули - шапки покрывающие голову, за исключением лица', tumbanostrojac 'человек, изготовляющий тумбаны - покрывала для головы', продавец шапок kapar и шляп - šeširdžija.

Чулками и носками торговали с̌arapar и kopičar; необходимо отметить, что обе формы образованы в первой половине XIX в. Форма rukavičar 'человек, выделывающий перчатки' встречается только в словарях с начала XVIII в.

Украшением тканей занимались čipkar, изготовляющий кружева, prhalar и resar, обозначающие 'того, кто изготовляет бахрому для женской одежды' и 
skutokrojac или skutošavac - мастер, занимающийся вышивкой. Подрубку тканей и одежды осуществлял мастер под названием žinjičar.

Первыми зафиксированными торговцами пуговиц были gumbar (из венгер. gomb 'пуговица') и kорс̌ar (из тур. qорс̌а 'застежка'); обе формы впервые упоминаются в XVII в. Турецким заимствованием является и слово kazaz, обозначающее человека, который продает шелковые пуговицы. Названия petljar и pucetar в этом же значении появились в начале XIX в.

В значении изготовителя поясов с XVII в. встречаются лексемы pasar и tkaničar, причем вторая со временем утратилась.

В сербском языке существовало более десяти слов, обозначающих человека, который шьет одежду. Самое древнее из них, - šavac, встречается и в других славянских языках, правда в укр., польск. и чешск. в значении 'человек, изготовляющий обувь'. Следующий материал показывает какие профессии в первой половине XIV в. пользовались наибольшей популярностью:

A kovačije, i zlatarije, i sedlarije, i šьvьci, i strıgunije, i vsi majstorije da robotaju i orju jako i sokalnici (А кузнецы, ювелиры, торговцы седлами, ткачи, кожевники, и все мастера пусть работают как крепостные). (Uroš III osniva Dečane, 1330), Mon. serb. 98.

Формы šivač и šivac записаны авторами конца XVII и первой половины XVIII в. соответственно, и в некоторых районах употребления сербского языка встречаются до сих пор. В отличие от них, лексема švelac зафиксирована только в одном документе последних десятилетий XVII в.

Со второй половины XV в. форма krajač использовалась как фамилия, а с XVI в. в интересующем нас значении:

Krajača, da se plati, dano mu je dva talira (Швецу за работу дано два талира). Mon. croat. 251.(1550).

На век позже появилась форма krojač, которая употребляется и в современном сербском языке, в отличие от слова terzija 'портной', употреблявшегося только в языке XVII в.

Заимствованное из венгер. szabó 'человек, который шьет одежду' слово sabol отмечено в словарях с конца XVII в. У одного писателя второй половины XVIII в. встречается написание sabo.

Также заимствованием, из немец. der Schneider 'портной', является употребляющаяся с конца XIX в. форма šnajdar (в Славонии šnajder).

5. В средние века торговцы продавали не только новую, но и поношенную одежду и старые тряпки. На Руси этим занимались трунникъ, тряпишникъ и ветошникъ: 
Ветошнику Ивашку Корнилову за однорядку бълу еренкову 2 р[убля]. Куплена къ шатерному дълу. Кн. прих. -расх. Каз. пр., 78. 1614 г.

Местом продажи служил ветошный рядъ рынка.

В Сербии все слова, обозначающие торговца трунными товарами, имели в своей основе star-. Самым ранним является зафиксированная в XVII в. форма starinoprodajac. Значительно позже документы отмечают варианты staretinar, starinar и starudar.

Лавка, в которой продавалось старое платье, называлась bit-pazar.

6. Судя по письменным источникам, основная масса слов, характеризующая торговца тканями и изделиями из ткани, в русском языке сложилась в XVI-XVII вв., а с XVII в. функционирует чрезвычайно богатый набор слов и составных наименований, служащих для обозначения торгующего человека, занятого данным видом деятельности.

Сербские материалы показали, что в самых ранних памятниках зафиксированы также общеславянские слова. С развитием торговли изменилась и торговая лексика, в лексике данной группы появилось большое число заимствований из турецкого, греческого, немецкого, венгерского.

\section{ЦИТИРОВАННАЯ ЛИТЕРАТУРА}

Байович 2015: Е. Р. Байович, Развитие торгово-экономической лексики 8 русском языке: лексема ярмарка в сравнительно-историческом и сопоставительном аспектах. - Српски језик, број XX, Београд, c. $711-719$.

Байович 2016: Е. Р. Байович, $K$ вопросу о формировании торгово-экономической лексики в русском и сербском языках (названия торговиеев изделий из металла). - Српски језик, број XXI, Београд, с. 159-164.

Мароевич 2002 : Е. Мароевич. Слово торг в русской и сербской лексикографической традиции. - Сборник научных трудов. И. И. Срезневский и современная славистика: наука и образование. Рязань, c. $76-78$.

Мароевич 2002 : Е. Мароевич. Слово товар в русской и сербской лексикографии. - Сборник Восточнославнская историческая лексикография на современном этапе. Москва, с. 153-157. 
Мароевич 2004: Мароевич Елена. Торгово-экономическая лексика в памятниках Древней Руси XI-XVII вв. (в сопоставлении с сербскими источниками). Москва, 16 с.

Речн. ист. хорв. серб. 1881-1976: Rječnik hrvatskoga ili srpskoga jezika. Zagreb.

СлРЯ XI-XVII вв. 1975-2008: Словарь русского языка XI-XVII вв. Выпуски $1-28$.

\section{ФОРМИРАЬЕ ТРГОВИНСКО-ЕКОНОМСКЕ ЛЕКСИКЕ У РУСКОМ И СРПСКОМ ЈЕЗИКУ (НАЗИВИ ТРГОВАЦА ТКАНИНАМА)}

\section{Рези м е}

У овом раду се разматра историја ширења и семантичког развоја назива трговаца тканинама у руском и српском језику са компаративно-историјског и конфронтативног аспекта. Истраживање се базира на материјалу Картотеке староруског језика, на основу које се издаје Речник руског језика XI-XVII века. Прво се прати историја назива трговаца тканина, делова одеће и ношене одеће у руском језику, затим се разматра историја ових назива у српском језику.

Циљ рада је да допринесе идентификацији и опису лексике трговинских појмова у руском и српском језику током векова, њиховом поређењу и анализи помоћу података које дају споменици писмености (филолошке потврде) и историјски извори и историјска истраживања (историјске потврде).

Кључне речи: историјска лексикологија, трговинско-економска лексика, називи трговаца тканинама.

Јелена Р. Бајовић 